\title{
Exploring Cultural Values Through Banjarese Language Study
}

\author{
Zulkifli \\ Indonesia Language Education Department \\ Faculty of Teacher Training and Education \\ Universitas Lambung Mangkurat \\ Banjarmasin, Indonesia \\ zulkiflimusaba59@gmail.com
}

\begin{abstract}
Culture as a human creation is constantly evolving, as well as experiencing change, along with the dynamics of the life of its supporting people. Every culture has some cultural values that become a part of the wisdom of its people. These values can be found through language as an important element in culture. Therefore, the study of language is important if associated with the exploration of cultural values in a society. It also applies to the study of Banjarese cultural values. The study of Banjarase language can be used to the language use, through sentences, both revealed through the use of the language in the association, as well as in the use of the language that goes into the literary field. The Banjarese language has long become the daily language for Banjarese people. Banjarese language from the past until now, can survive, live and expand because it is inseparable with the supporting environment or Banjarese language community itself. Therefore, some Banjarese cultures are revealed through the Banjarese language. Cultural values that are already inherent in the life of Banjarese people practically become guidance as well as a prompter for the progress of Banjarese society, especially in fostering characters and enhancing positive attitude, including strengthening the unity of people as a local Banjarese cultural community.
\end{abstract}

Keywords: cultural values, language study, Banjarese language

\section{INTRODUCTION}

Culture as a human creative work is constantly evolving, changing from time to time, in accordance with the dynamics of its supporting society. Society consists of people who live together, and produce culture. In short, there is no society that has no culture, or otherwise, there is no culture without a supporting society [1]. This shows that culture belongs to the society, something valuable and beneficial to support the society. Hence, it is very natural that a society seeks to preserve, as well as to develop their culture so that the supporting society increasingly feels the benefits of their own culture. Culture also means the whole of human ideas and works, which must be familiarized by learning [2].

Culture as a work of human certainly experiences changes and development time by time based on the dynamics of the supporting society. Every change and development is expected to be able to improve the welfare of those who support the culture itself. Essentially, humans do not want to survive in certain circumstances, but they want to go to better conditions, more pleasant circumstances, and circumstances that further ensure the survival of their lives and the next generation.

One element of culture that is also highly regarded by the supporting society is the language with all things related in it, including those concerning cultural values. In other words, the assessment of the language will be able to uncover the cultural values that apply in the language itself. Indeed, it must be admitted that language is a reflection of people's lives [3]. Thus, the form of language as a part of culture can reveal the various things that exist in society, including cultural values. Another thing that also needs to be understood that not all members of the society are able to take the values of the culture through the language they use every day. Therefore, assessment of the value of culture through the study of language is important to do so the public society can wholeheartedly feel the benefits of language.

\section{DISCUSSION}

\section{A. Cultural Values}

Cultural values are conceptions that live in the minds of some societies, about the things they consider most valuable in life [2]. In other words, cultural values are one of the guided references by citizens in behaving and responding to what is facing them in society, including in their private life.

Cultural values that become the reference for the community must have been gifted and still remain relevant to the present life. On the other hand, as a culture undergoes change and development, there has also been intercultural contact. Therefore, a shift in cultural values also is fully unavoidable [4]. This is related to the dynamics of people's lives as well as one of the driving forces of the development of a culture.

\section{B. Disclosure of Cultural Values through Banjarese Language Studies}

In this section, the author proposes some cultural values (Banjarese culture) through the study of Banjarese language. Therefore, before further discussing the cultural 
values through the study, the Banjarese language should be mentioned first briefly. Banjarese language is one of the local languages in South Kalimantan. It is the lingua franca which applies to not only residents of South Kalimantan, but also to Banjarese people who live in other parts of Kalimantan, such as Central Kalimantan [5].

Banjarese language is also widely used in the area of Sumatra, for example in Tambilahan, Jambi, Kuala Tungkal, and in some areas in North Sumatra [6]. Banjarese language speakers in Sumatra are Banjarase people (descendants) who have moved hundreds of years ago from a residential area of Hulu Sungai and they are then settled in Sumatra. Their predecessors migrated in search of livelihood, mostly as farmers, planters, and some of their status as scholars and those who oppose the Dutch colonists [7]. Banjarese dispersive power is quite strong, so Banjarese language is widely used in some areas in Indonesia.

As a language that has many speakers, Banjarese language makes the cultural values existence remains strong. Therefore, one of the identities of Banjarese people is the language itself. Therefore, Banjarese cultural values are revealed through the use of Banjarese language and Banjarese literature. To find Banjarese cultural values can be done by examining or studying the language.

In order to reveal or discover cultural values through the language, the elements of language that can be studied are words and sentences. Words and sentences can be applicable in general, namely the form of language itself and specifically the language in the literary work.

\section{1) Value of Kinship}

The word bubuhan contains the meaning of family, descendent, regionality, profession similarity, which include meaningful kinship, although it is not only aimed at one offspring. The use of the word bubuhanhas shown that there is a family value. Thus, for those who are included in the scope of the bubuhan, there is a sign of a sense of familiarity. It can also be associated with the word papadaan which also means family.

\section{2) Responsibility Value}

The word sandang that means accept / bear / hold is usually directed at someone who commits an act in which later he/she is asked to assume the risks or consequences. The word sandang indicates that one must wholeheartedly accept any consequences for his/her actions. In proverbs (literary section), there are some phrases that have the value of responsibility, such as wani manimbai lunta, wani jua manyalami (dare to throw nets, dareto dive-if their nets hit a barrier at the bottom of the river). The purpose of this proverb is that someone must take responsibility for what they do, not to be transferring the risk to another person. Withthese values of responsibility, it encourages Banjarese people to be careful in doing an act. Banjarese people are advised by their parents or family to consider anything to be done, and not to have regrets later.

\section{3) Value of Deliberation}

The word padirakan means negotiate, discuss, or talk together. If there is a problem or disagreement, usually Banjarese people take a step of pandirakan, so the problems can be resolved, without causing unfavorable things for other people.

\section{4) Value of Upholding Righteousness}

The phrase mun bujur saurang, dalas hangit kada baundur (if I am correct, even though I get burnt, I will not give up) indicates that a person if he/she is holding the right thing, then he/shedo the best to establish the truth or defend the truth. This phrase encourages people to struggle for truth and to stay in truth.

\section{5) Value of Hard Work}

A saying "Bacari limbui paluh (working until fully get sweaty)" illustrates that a person works hard to earn a living. This phrase encourages one to work sincerely, both physically and mentally. In fact, some Banjarese people literally work in sweating, such as when working in the fields, gaining diamonds, cutting wood, and so on. Everyone is required to work diligently, and do not waste the opportunity. In other words, everyone must be productive.

\section{6) Value of Friendship Faithfulness}

Sarantang-saruntung expression means someone has a very solid best friend. The relationship is really bonded. They care for each other, and understand each other's circumstances. Other expression that conveys the same meaning is samuak saliur.

\section{7) Value of Helping Each Other}

Hidup bapapatulan means that in social life we should help each other, and we do not be selfish. In Banjarese culture, for examplein a wedding party, each citizen comes to prepare for the wedding, both before the party, at the party, and when the party ends.

\section{8) Values of Health}

The phrase jangan baling kundi kalambu (do not just stay in bed) means that everyone should be productive, and should keep on working. Thus, one's body will be healthier. Then, the phrase jangan hantup tarus (do not eat without limit) is intended for a person who regulates his/her diet, does not eat carelessly, and does not overeat since overeating can cause illness.

\section{9) Value of Seeking for Knowledge}

Badadangar phrase means that someone is recommended to seek for knowledge, in particular seek for religious knowledge. This is in accordance with one of Banjarese identity which is related to Islamic identity. If someone is not familiar with the teachings of Islam, it is usually advisable to meet a religious teacher, so one can study more about religion. 


\section{0) Value of Time Use}

The proverb bagawi kada tahu di waktu (working without considering the time) means that it is very important that one should utilize time well, so a balance for both physically and mentally can be realized.

\section{1) Value of Respecting Others}

Banjarese people are very concerned that everyone must appreciate others, especially people who give good deeds to him. Expression of the need to respect other people includes jangan salah pambalas (do not get wrong in paying people's good deeds). Indeed, in this life, everyone must receive the goodness from others, family, even others who have no family relationship. People do not live alone, and they always need someone else, either directly or indirectly. The aforementioned Banjarase phrase also suggests how important it is to live together and to live in mutual respect.

\section{2) Value of Self-Introspection}

The expression susurisisitapih (edgeing the side of the glove) is addressed to every person that likes to check out his/her own weakness and deficiency. A person should be neither unmindful of himself/herself, nor arrogant. With susurisisitapih expression, then someone hopefully finds deficiencies himself/herself and tries to fix it.

\section{3) Value of Enviromental Care}

Old Banjarese people often advise their children with the phrase jangan bararigat (Do not throw any trash in the wrong place), meaning that each person should maintain cleanliness, keep the surrounding environment in order to create the sight of comfort, and keep the environment healthy. The expression ganang anak cucu (remember your children and grandchildren) also means that everyone should maintain and utilize the environment well. Everyone is asked to plant anything in order to be rewarded for the results by their own children, even their grandchildren.

\section{4) Value of Self-Pleasure}

Banjarese people often say handak jua bararamian (I also want to enjoy the fun) means that as humans, everyone needs to give a chance for himself in order to feel pleasure, either by enjoying games, music, sports, and just hanging out with friends for a chat leisurely.

\section{5) Value of Speaking Politely}

Cultural value that someone speaks with a polite expression is embodied in baapik-apikbapandir (be careful to speak). This expression is addressed to everyone to keep their speech from hurting their interlocutor. The speaker should pay attention to and respect other persons. Even Banjarese people give advice to others in order to speak in babukubaruas (speaking in needs, politely, giving the opportunity to the listener to speak too).

\section{CONCLUSION}

The explanation in this article is a small part of language form and literature whichexist in Banjarese cultural. Cultural values that are revealed through these languages and literature can also be applied generally. It relies on the reason that all societies have their own languages and literatures with many cultural values in them.

\section{REFERENCES}

[1] S. Soekanto, Sosiologi Suatu Pengantar, Jakarta: PT Raja Grafindo Persada, 2004

[2] Koentjaraningrat, Kebudayaan Mentalitas dan Pembangunan, Jakarta: PT Gramedia, 1985.

[3] E. Chaika, Language The Social Mirror, London: Newbury House Publisher, INC, 1982.

[4] H. Hendrawan, Materi Muatan Lokal Kebudayaan Banjar Banjarmasin: PemerintahProvinsi Kalimantan Selatan-Dinas Pemuda, Olahraga, Kebudayaan dan Pariwisata, 2011.

[5] M. Mugeni, Ungkapan Bahasa Banjar, Banjarbaru: Balai Bahasa Banjarmasin, 2004.

[6] D. Kawi, Telaah Bahasa Banjar, Banjarbaru: Scripta Cendekia, 2011.

[7] S. Ideham, Urang Banjar dan Kebudayaannya, 2005. 